\title{
三次元変位測定システムによる 木質構造物の大変形測定
}

\section{MEASUREMENT OF LARGE DEFORMATION FOR TIMBER STRUCTURE WITH THREE- DIMENSIONAL MEASURING SYSTEM}

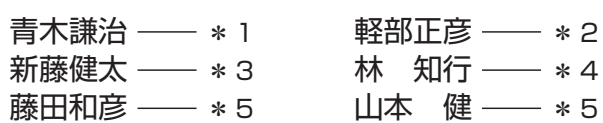

キーワード

三次元測定, 大変形測定, 載荷破壊試験, 木橋

Keywords:

Three-dimensional measuring system, Measurement of large deformation, Destructive loading, Timber bridge

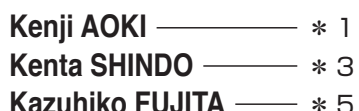

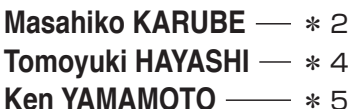

The experiment of timber structures often extends to the large deformation area. However, an appropriate measuring method of large deformation is not in existence. We carried out the static loading test to the rebuilt timber truss bridge of the length of $36 \mathrm{~m}$. In this test, a threedimensional measuring system that used wired displacement transducers was developed. The two kinds of vertical displacements obtained from transducers and a surveying instrument by numerical calculation showed almost good agreement.
1.はじめに

木質構造物の静的加力試験等を行う場合、 $\mathrm{RC}$ 造や $\mathrm{S}$ 造等の他構 造に比べて大変形領域にまで及ぶ測定を行う場合が多い。例えば、 木造の耐力壁の水平せん断試験を実施する場合、標準的な試験方法 ${ }^{1}$ に定められた終局時の試験体頂部変形量は約 $180 \mathrm{~mm}$ 程度であり、 貫構造等の伝統的な軸組構法耐力壁の場合は変形の進行に伴って耐 力が漸増するため、 500 700mm という加力装置の限界まで加力す る場合もある ${ }^{2,3)}$ 。とのような試験を行う際には大変形に追従可能な 測定装置が必要となるが、現状はワイヤー式の変位計を用いるか、 ストローク式の変位計の盛り換え等を行っているため、変形の進行 に伴う試験体高さの変化に追従できず、正確な変形量の測定ができ ていない可能性がある。また実大建物の振動台実験でも、層間変形 量の測定にはワイヤー式変位計が用いられる事が多いが 4)、一方向 の変形のみを測定するような設置方法であるため、三次元入力等の 場合には層間変形を正しく測定できているか疑問が残る。

一方、近年の振動台実験などでは、画像計測技術を用いた大変形 測定が行われるようになり、建物の倒壊挙動まで測定できる手法と して活用されている ${ }^{5,6)}$ 。そこで筆者らも、本稿で報告する木造トラ 又橋の載荷破壞試験実施に伴い、同様の画像計測の事前検討を行っ たが、晴天の屋外において長時間にわたり安定して測定することは 困難であり、採用を断念した経緯がある。

このような背景から、木造トラス橋の三次元変形（特に鉛直方向 の変形）を正確に測定する方法を新たに検討する必要が生じ、ワイ ヤー式変位計を三角錐状に設置して数值計算で三方向成分を求める 方法を検討した。その結果、本測定方法によって木造トラス橋下弦 材の三次元的な動きを把握することができ、同時に行った測量機器 を用いた光波測定による測量結果とも概ね良好な一致を見せた。

本手法は、特殊な装置を用いることなく、通常の構造実験で用い るワイヤー式変位計とデータロガーがあれば測定が可能であり、木
質構造以外の大変形を伴う構造実験全般にも応用することができる ため、試験概要と共にその測定技術を報告する。

\section{2. 木造トラス橋の載荷破壊試験}

\section{1 試験の全体概要}

今回の試験対象となった木造トラス橋は、1990 年 5 月に広島県立 山野峡自然公園内の歩道橋として架設された径間 $36 \mathrm{~m}$ の下路式木 造単純トラス橋「かっぱ橋」である。部材は、集成材ベイマッ 1 級 （当時の JAS）に天然系防腐塗料を塗布したもので、断面寸法は上 下弦材が幅 $220 \times$ 厚さ $262 \mathrm{~mm}$ 、斜材が幅 $220 \times$ 厚さ $170 \mathrm{~mm}$ 、接合部 はコの字型金物を用いた鋼板添え板二面せん断ボルト接合である。

この木造トラス橋は、2003 年 12 月に 13 年という短い供用期間を 終えて解体撤去された ${ }^{7)}$ 。筆者らは、解体に際して全ての部材と接 合部品を回収して屋内保管していたが、2007 年 3 月に架設当初から の部材と接合部品だけを使って木橋を再組立した ${ }^{8)}$ 。それ以降、各 種非破壊調查を元に部材劣化の内容および評価方法について検討し てきたが、2008 年 6 月に、残存耐力を実際に検証する目的で載荷実 験を実施し、破壞に至らしめた ${ }^{9)}$ (写真 1)。

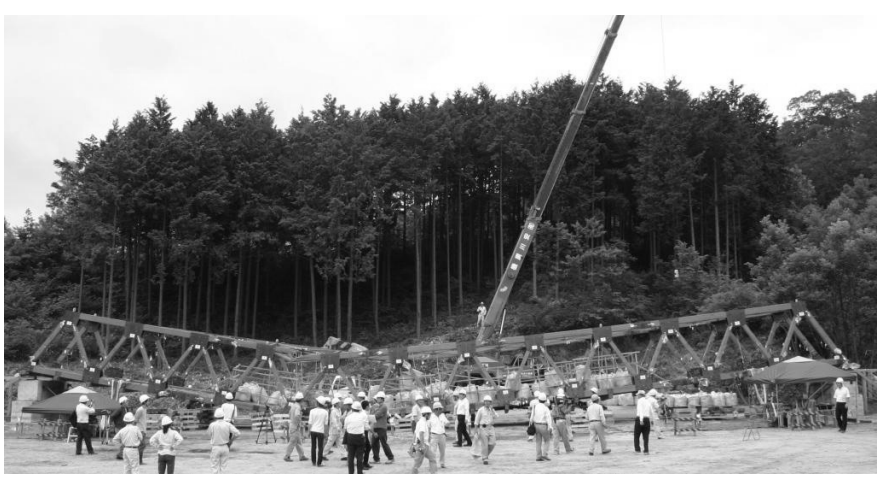

写真 1 載荷試験により破壊した木造トラス橋

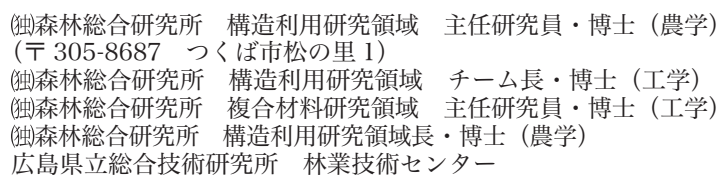

\footnotetext{
Senior Researcher, Dept. of Wood Engineering, Forestry and Forest Products Research Institute (FFPRI), Dr. Agr.

Team Leader, Dept. of Wood Engineering, FFPRI, Dr. Eng.

Senior Researcher, Dept. of Wood-Based Material, FFPRI, Dr. Eng.

Director, Dept. of Wood Engineering, FFPRI, Dr. Agr.

Forestry Research Center, Hiroshima Prefectural Technology Research Institute
} 


\section{2 載荷 $\cdot$ 測定方法}

載荷破壊試験は、土のうを順次載荷することによる一方向単調載 荷とした。移動式クレーンを使い、木橋の上弦材間にある水平ブレ 一スをかわしながら、重さ約 $350 \mathrm{~kg}$ の土のうを図 1 に示寸橋長中央 $1 / 2$ の範囲に、橋長および幅員方向に対してできるだけ対称になる よう床版上に積載する方法を採用した。木橋にとって最も厳しい載 荷条件は、橋中央に人や貨物等が集中した場合を想定した中央集中 載荷と思われるが、作業者・測定者の安全を確保しつつ、低重心か つ効率的に載荷することを目的として、橋長中央 $1 / 2$ 部分に土のう を積載する方法を採用するに至った ${ }^{9)}$ 。

載荷荷重は、木橋と橋台との間に設置した 4 台のロードセルで支 点反力を測定することによって求めた。測定については、木橋全体 の変形や接合部の相対変位を測定するために計 154 台の変位計を設 置し、各部材にはひずみゲージ（計 172 枚）を貼り付け、2 系統の データロガーにて土のうの載荷速度等に関係なくインターバル測定 を行った。本報告では木橋下弦材の三方向変位測定と、それを補完 する目的で行った光波測定の $2 つ に$ 絞って詳細に報告するので、そ の他の測定点等については既報告 ${ }^{9,10)}$ を参照されたい。

図 1 には節点番号と方向の定義を示した。

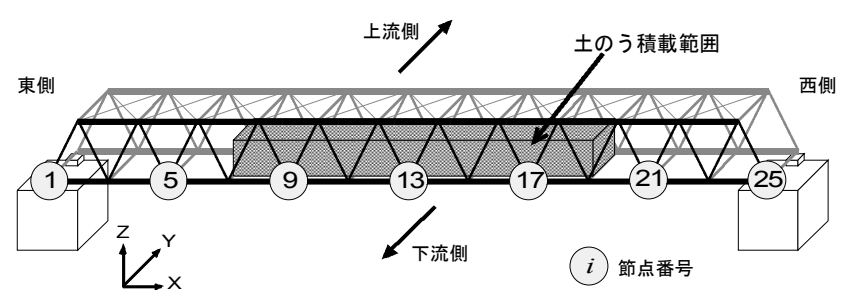

図 1 節点番号と方向の定義

\section{3 ワイヤー式変位計による三次元測定}

本研究の対象である木造トラス橋の場合、木橋全体の変形性状を 把握することは最も基本的な測定事項であり、特に下弦材の鉛直方 向変形を正確に測定することが重要となる。しかしながら、土のう 載荷に伴う変形の進行は、必ずしも鉛直下方のみとは限らないため、 三次元的な動きを測定する必要があった。そこで筆者らは、写真 2 に示すような測定装置を作成した。

本装置は、ワイヤー式変位計を正三角形状に配置した定規を作成 し、定規中心直上に測定対象点が来るように設置するものである。 図 2 に示寸下弦材の三次元変位測定箇所 10 点の直下に杭を打ち込ん でその頂部を水平調整し、その上に予め変位計を中心から等距離(中 心からの距離を $1 \mathrm{~m}$ に設定）に固定した定規を設置した。変位計は 定規平面に対して 60 度の角度で設置してあり、概补、稜線 : 中心か らの距離 : 高さの比が $2: 1: \sqrt{3}$ とっている。変位計から測定対象点 までのワイヤー長さは、測定対象点から定規中心までの鉛直高さを 測ることによって計算で求めることが可能であり、試験開始後はワ イヤー式変位計の相対変形量を記録することによって、測定点の三 次元的な動きをXYZ 方向成分に分けて算出することが可能となる。 ワイヤー式変位計の測定ストロークは、想定される変形量に対応す る長さがあれば十分であることから、斜辺長さの不足分は直径 $1 \mathrm{~mm}$ のワイヤーを延長した。測定点までの距離が長い場合には、ワイヤ 一の重量等によるたわみや風による影響も無視できなくなるが、今 回の実験に関してはそれらの影響は認められなかった。
なお、木橋の支点部分 4 箇所は橋台上にあり、変形量も小さいこ とが予想されたため、XYZ方向からストローク式変位計を直接下弦 材端部に当てることで変位を測定することとした。

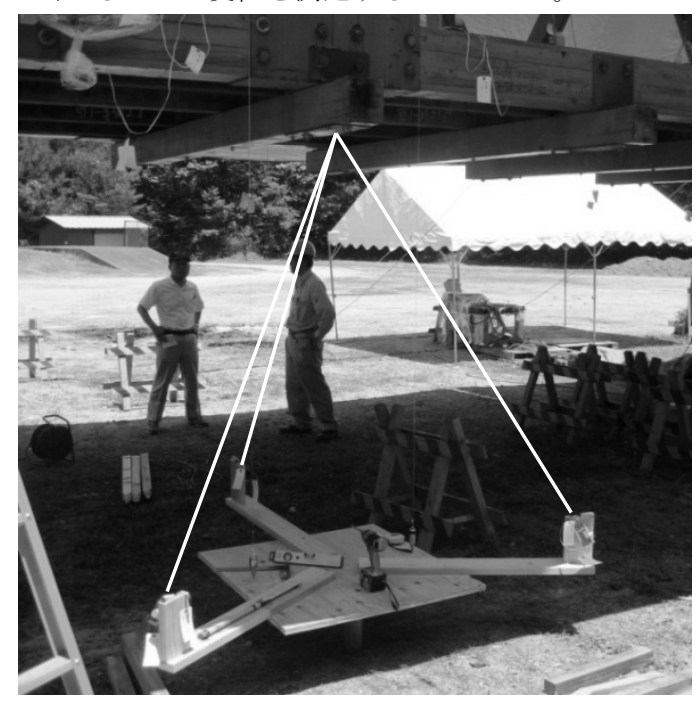

写真 2 三次元測定システム（白線は写真上で追加）

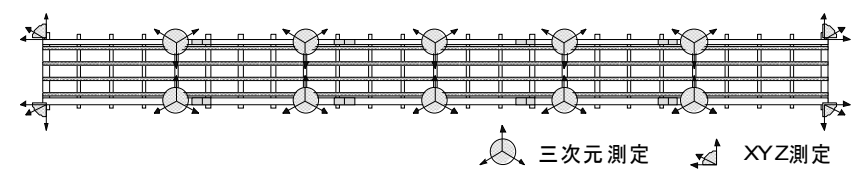

図 2 下弦材の変位測定箇所（平面図）

\section{4 トータルステーションを用いた光波測定}

変位計を用いた三次元測定を補完する目的で、測量用機器である トータルステーションを用いた光波測定を行った。本システムは、 測定したい場所に予めプリズムターゲット (又はシールターゲット) を設置し、初期位置を手動で測定した後は自動的に機械が巡回測定 する装置であり、鉄塔などの大型構造物の載荷実験などで測定実績 がある。木造卜ラス橋の載荷破壊試験がやり直しのきかない実験で あること、変位計等による測定とは全く別系統の測定も平行して行 うことで不測の事態にも備えたいことなどから、変位計による測定 を補完する測定として採用した。

今回は、自動追尾型トータルステーション(TCA1100S)を使用し、 図 3 に示寸ように、上弦材の上部 10 点にプリズムターゲットを、 下弦材の下流面 7 点にシールターゲットを取り付け、木橋下流側に $50 \mathrm{~m}$ 程度離れた斜面上部から 3 次元座標測定を行った（写真 3 ）。 測定時間は 1 点につき $3 \sim 5$ 秒とデータロガーに比べると時間を要し 測定誤差は距離 $50 \mathrm{~m}$ で約 $0.75 \mathrm{~mm}$ 、最小表示精度は $1 \mathrm{~mm}$ とのことで あった。得られた座標データをもとに初期值からの相対移動値を求 めることによって、各測定点の変形量を求めた。

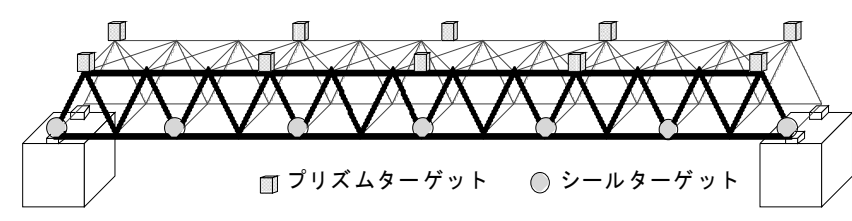

図 3 測量用ターゲット設置位置 


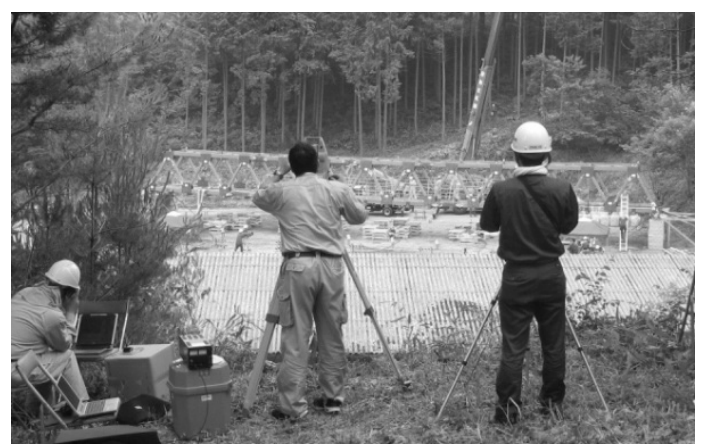

写真 3 光波測定の様子（初期位置測定時）

\section{5 試験結果の概略}

土のう 26 袋 $(94.4 \mathrm{kN})$ を載荷した時点で、橋長中央部付近の上流 側下弦材が破断して傾いた（写真 4 の円部分）。この一次破壊におけ る破断箇所は、解体撤去時の非破壊調查より部材の劣化が指摘され ており、試験前に破断箇所として予見していた箇所の一つであった。 その後は破断した上流側への載荷は土のうの落下や木橋の予期せぬ 破壊が予想されて危険なため、下流側に偏った載荷を続けた。53 袋

$(189.7 \mathrm{kN})$ を載荷した時点で下流側の上弦材がトラス格点間中央部 分で圧縮破壊し、最終破壊に至った (写真 5 の円部分)。この部材に 関しても、長期間の暴露により部材上面が溝状に腐朽しており、劣 化の進行が指摘されていた箇所であった。

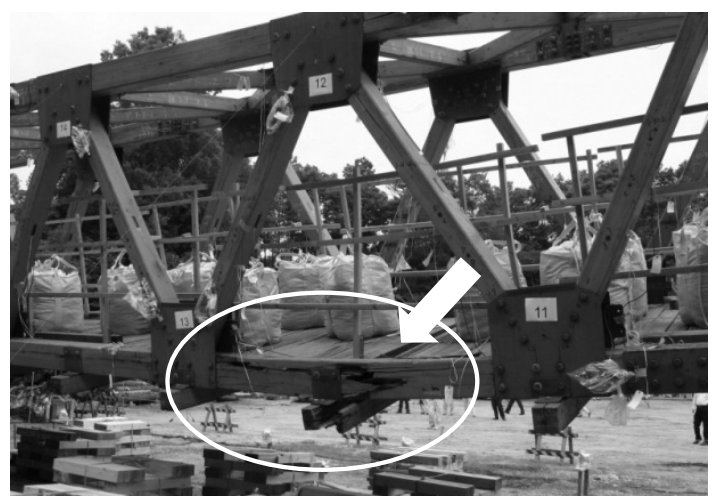

写真 4 部材破壊状況（一次破壊）

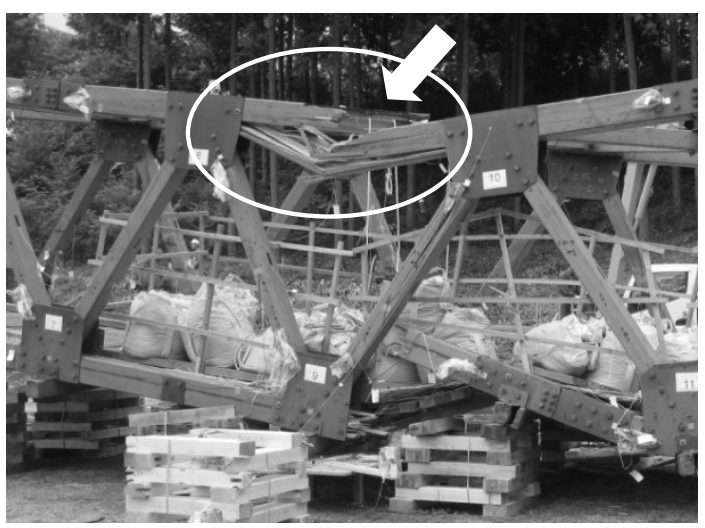

写真 5 部材破壊状況（二次破壊）

\section{3. 三次元測定の計算処理方法}

$\mathrm{X}, \mathrm{Y}, \mathrm{Z}$ 空間において、図4のように三角錐の頂点 4 点の座標を $\mathrm{A}\left(\mathrm{x}_{\mathrm{A}}\right.$ $\left.\mathrm{y}_{\mathrm{A}}, \mathrm{z}_{\mathrm{A}}\right) 、 \mathrm{~B}\left(\mathrm{x}_{\mathrm{B}}, \mathrm{y}_{\mathrm{B}}, \mathrm{z}_{\mathrm{B}}\right) 、 \mathrm{C}\left(\mathrm{x}_{\mathrm{C}}, \mathrm{y}_{\mathrm{C}}, \mathrm{z}_{\mathrm{C}}\right) 、 \mathrm{D}\left(\mathrm{x}_{\mathrm{D}}, \mathrm{y}_{\mathrm{D}}, \mathrm{z}_{\mathrm{D}}\right)$ とし、辺 $\mathrm{AD} 、 \mathrm{BD} 、$ $\mathrm{CD}$ の長さをそれぞれ $\mathrm{L}_{1}, \mathrm{~L}_{2}, \mathrm{~L}_{3}$ とおくと、

$$
\begin{aligned}
& \mathrm{L}_{1}=\sqrt{\left(\mathrm{x}_{\mathrm{A}}-\mathrm{x}_{\mathrm{D}}\right)^{2}+\left(\mathrm{y}_{\mathrm{A}}-\mathrm{y}_{\mathrm{D}}\right)^{2}+\left(\mathrm{z}_{\mathrm{A}}-\mathrm{z}_{\mathrm{D}}\right)^{2}} \\
& \mathrm{~L}_{2}=\sqrt{\left(\mathrm{x}_{\mathrm{B}}-\mathrm{x}_{\mathrm{D}}\right)^{2}+\left(\mathrm{y}_{\mathrm{B}}-\mathrm{y}_{\mathrm{D}}\right)^{2}+\left(\mathrm{z}_{\mathrm{B}}-\mathrm{z}_{\mathrm{D}}\right)^{2}} \\
& \mathrm{~L}_{3}=\sqrt{\left(\mathrm{x}_{\mathrm{C}}-\mathrm{x}_{\mathrm{D}}\right)^{2}+\left(\mathrm{y}_{\mathrm{C}}-\mathrm{y}_{\mathrm{D}}\right)^{2}+\left(\mathrm{z}_{\mathrm{C}}-\mathrm{z}_{\mathrm{D}}\right)^{2}}
\end{aligned}
$$

と表せる。

さらに、計算の簡略化のため、三角形 $\mathrm{ABC}$ を正三角形とし、 $\mathrm{Z}=0$ の $\mathrm{XY}$ 平面上に設置したとする。この時、 $\mathrm{A}$ 点の座標を $(0,-2 \alpha, 0)$ とおくと、B,C 点の座標はそれぞれ図 5 のように決まる。これを元 に(1)式を書き直すと、

$$
\begin{aligned}
& \mathrm{L}_{1}=\sqrt{\mathrm{x}_{\mathrm{D}}^{2}+\left(-2 \alpha-\mathrm{y}_{\mathrm{D}}\right)^{2}+\mathrm{z}_{\mathrm{D}}^{2}} \\
& \mathrm{~L}_{2}=\sqrt{\left(-\sqrt{3} \alpha-\mathrm{x}_{\mathrm{D}}\right)^{2}+\left(\alpha-\mathrm{y}_{\mathrm{D}}\right)^{2}+\mathrm{z}_{\mathrm{D}}^{2}} \\
& \mathrm{~L}_{3}=\sqrt{\left(\sqrt{3} \alpha-\mathrm{x}_{\mathrm{D}}\right)^{2}+\left(\alpha-\mathrm{y}_{\mathrm{D}}\right)^{2}+\mathrm{z}_{\mathrm{D}}^{2}}
\end{aligned}
$$

となる。

(2)式を $\mathrm{x}_{\mathrm{D}}, \mathrm{y}_{\mathrm{D}}, \mathrm{z}_{\mathrm{D}}$ について整理すると、

$$
\begin{aligned}
& \mathrm{X}_{\mathrm{D}}=\frac{\sqrt{3} \mathrm{~L}_{2}{ }^{2}-\sqrt{3} \mathrm{~L}_{3}{ }^{2}}{12 \alpha} \\
& \mathrm{y}_{\mathrm{D}}=\frac{-2 \mathrm{~L}_{1}{ }^{2}+\mathrm{L}_{2}{ }^{2}+\mathrm{L}_{3}{ }^{2}}{12 \alpha} \\
& \mathrm{Z}_{\mathrm{D}}=\frac{12 \alpha^{2}\left(\mathrm{~L}_{1}{ }^{2}+\mathrm{L}_{2}{ }^{2}+\mathrm{L}_{3}{ }^{2}-12 \alpha^{2}\right)-\mathrm{L}_{1}{ }^{4}-\mathrm{L}_{2}{ }^{4}-\mathrm{L}_{3}{ }^{4}+\mathrm{L}_{1}{ }^{2} \mathrm{~L}_{2}{ }^{2}+\mathrm{L}_{1}{ }^{2} \mathrm{~L}_{3}{ }^{2}+\mathrm{L}_{2}{ }^{2} \mathrm{~L}_{3}{ }^{2}}{6 \alpha}
\end{aligned}
$$

となり、三角錐頂部の XYZ 座標を求めることができる。

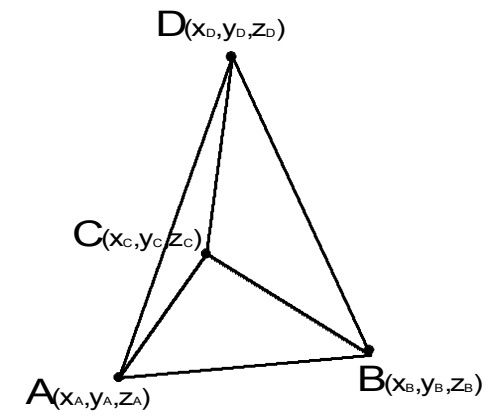

図 4 座標の定義

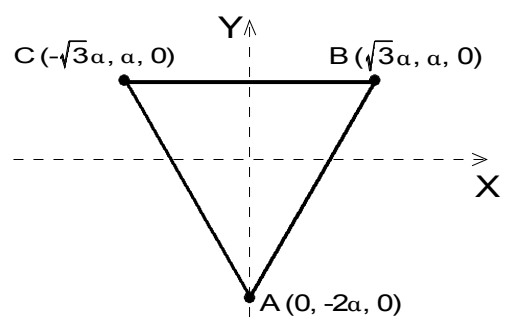

図 $5 X Y$ 平面上での座標の簡略化

\section{4. 測定結果の比較}

図 6 には、(3)式で求めた変位のうち、三次元測定の主目的であっ た鉛直方向の変位 $\mathrm{z}_{\mathrm{D}}$ を示した。初期值は測定用定規から測定対象点 までの高さとしており、実際には木橋のスパン中央が垂下していた ことから、支持点近くは高く、中央部の節点 13 が最も低くなってい る。載荷荷重が増えるにつれて徐々に変形が進み(高さが低くなり)、 $94.4 \mathrm{kN}$ 載荷時の一次破壊では、上流側下弦材の破断により上流側測 定点は急激に変形が進行した。下流側下弦材は一次破壊によって 3 倍程度に変形が増大したものの、そこで持ちこたえて二次破壊まで 
徐々に変形が進行していった。最終的には、二次破壊である載荷荷 重 $189.7 \mathrm{kN}$ の時点で、下流側上弦材の圧縮破壊により一気に木橋が 落下し、変位計防護用集成材の上に着地した。

図 7 には、一次破壊、二次破壊の前後における下弦材の変形性状 (鋁直変位のみ) を示した。一次破壊で上流側が一気に変形が進行 し、その形状を保ったまま二次破壊まで徐々に変形が進行していっ た様子が見てとれる。ワイヤー式変位計を用いた三次元測定から数 值計算によって変位を求める本手法によって、大変形に及ぶ測定が 正確に行えることが確認された。

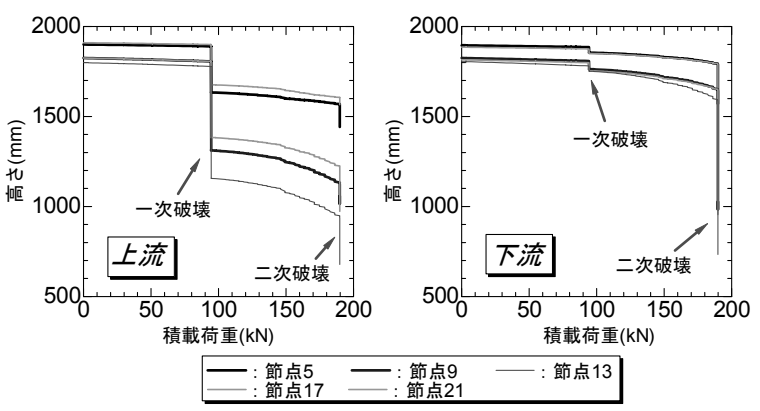

図 6 下弦材測定点の鉛直変位

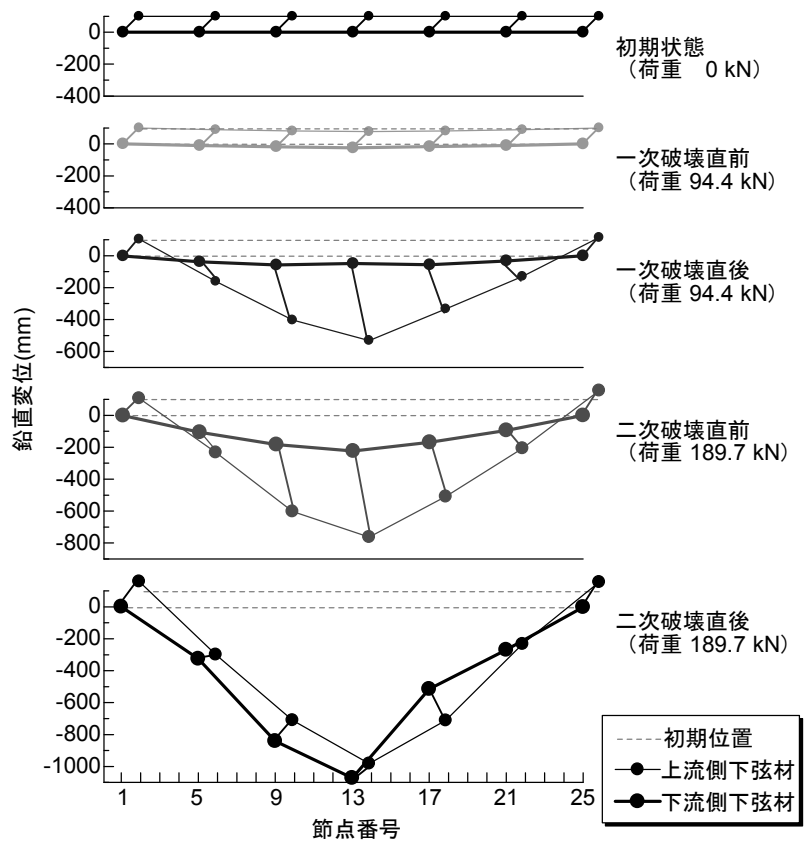

図 7 下弦材の変形性状

図 8 には、変位計による三次元測定とトータルステーションによ る光波測定の鉛直方向変位の比較を示した。下弦材のシールターゲ ットは下流側の下弦材側面のみにしか貼っていないため、下流側の みの比較となっている。また、二次破壊直前の光波測定は、測定時 間の短縮の目的から主要測定点のみの測定であったため、節点番号 $9,13,17$ の 3 点しか比較することができない。

両測定手法による変位は概ね良く一致しており、光波測定が木橋 下弦材の変形を正確に捉えていることが明らかとなった。なお、一 次破壊直後の誤差が若干大きいが、これは測定に時間を要する光波 測定と変位計による測定との測定時刻に差が生じ、一次破壊直後の 変形の進行による変位増分が生じたためと考えられる。その他の測
定では両測定方法の誤差は概ね $10 \mathrm{~mm}$ 程度以内で、变位に対する誤 差の比率では $10 \%$ 以下に収まっていた。

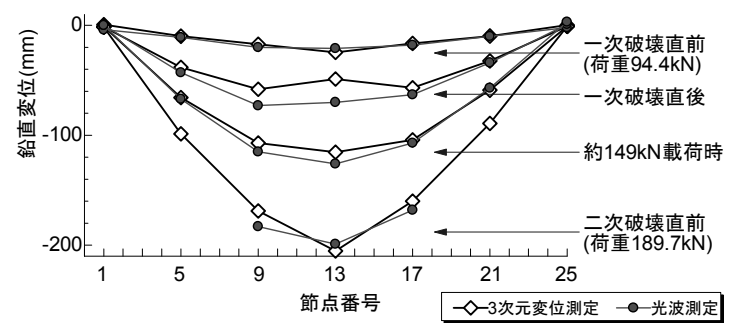

図 8 下流側下弦材の変位比較

\section{5.まとめ}

木質構造物の大変形測定に適用可能な、ワイヤー式変位計を三角 錐状に配置することによる三次元変位測定システムを採用し、得ら れた結果から数值計算で三方向の変形成分を算出する方法を検討し た。木造トラス橋の載荷破壊試験を通じてその信頼性を確認した結 果、三次元変位測定システムは木造トラス橋の動きを正確に捉えて おり、大変形を伴う様々な構造実験に応用可能な測定方法であるこ とが分かった。

\section{謝辞}

本研究は、独立行政法人森林総合研究所 運営費交付金プロジェク 卜「既存木橋の構造安全性を維持するための残存強度評価技術開発」 によって実施した。研究の実施にあたり、広島県立総合技術研究所 林業技術センターをはじめ、多くの方々のご協力を頂いた。ここに 記して謝意を表する。

\section{参考文献}

1）木造の耐力壁及びその倍率性能評価業務方法書，(財) 日本住宅・木材技術 センター, 2001

2）山田真澄，鈴木祥之，後藤正美，清水秀丸：単位木造フレームを用いた動 的・静的実験による木造軸組の耐震性能評価, 日本建築学会構造系論文集, 582, pp.95-102, 2004.8

3）青木謙治，杉本健一，軽部正彦，神谷文夫：製作後 27 年程度経過した土 塗り壁の水平せん断性能，木材工業，64(4)，pp.172-175，2009.4

4）橋本敏男：実大木造住宅の振動台実験の標準化について, Journal of Timber Engineering, 18(6), pp.175-179, 2005.11

5）藤田聡, 古屋治, 豊嶋学, 三輪晋也, 腰原幹雄 : 既存木造住宅の而震性向 上に関する総合的研究 その 8 実大振動台実験における画像計測方法, 日 本建築学会大会学術講演梗概集， C-1，pp.213-214，2003.9

6）古屋治，藤田聡，五十田博，桘本敬大，箕輪親宏：震動台による既存木造 住宅の耐震性能検証実験 その 14 画像計測法による三次元動的応答計測, 日本建築学会大会学術講演梗概集， C-1，pp.393-394，2006.9

7) 藤田和彦, 軽部正彦, 宮武 敦, 渡辺 浩：13 年で架け替えられた木橋の 経緯と履歴，土木学会 第 3 回木橋技術に関するシンポジウム論文報告集， pp.127-132，2004.7

8）軽部正彦, 藤田和彦, 築山健一, 長尾博文, 宮武 敦 : 13 年で架け替えら れたトラス木橋の再組立とその変化, 土木学会 第 6 回木橋技術に関するシ ンポジウム論文報告集，pp.113-118，2007.8

9) 軽部正彦, 林知行, 加藤英雄, 宮武敦, 新藤健太, 青木謙治, 藤田和彦: 13 年の供用履歴を持つ既存木橋の載荷破壞試験, 第 7 回木橋技術に関する シンポジウム論文報告集，pp.129-134，2008.8

10）軽部正彦, 青木謙治, 山本健 他: 再組立した既存木造トラス橋の載荷破 壊試験（その 1〜その 6), 第 59 回日本木材学会大会研究発表要旨集 (CD-ROM)，H15-1615b〜H15-1645b 及び PH015〜PH017，2009.3

[2009 年 2 月 20 日原稿受理 2009 年 4 月 30 日採用決定］ 